\title{
GMR
}

\section{Association of interleukin-6 gene polymorphisms and circulating levels with keloid scars in a Chinese Han population}

\author{
X.J. Zhu' ${ }^{1 *}$ W.Z. $\mathrm{Li}^{2 *}$, H. Li ${ }^{2}$, C.Q. Fu ${ }^{3}$ and J. $\mathrm{Liu}^{4}$ \\ ${ }^{1}$ Department of Clinical laboratory, Zhangjiagang First People's Hospital, \\ SuZhou, China \\ ${ }^{2}$ Department of Clinical Laboratory, Taixing People's Hospital, Taixing, China \\ ${ }^{3}$ Department of Clinical Laboratory, Zhangjiagang Leyu Hospital, Suzhou, China \\ ${ }^{4}$ Department of Dermatology, Taixing People's Hospital, Taixing, China \\ *These authors contributed equally to this study. \\ Corresponding author: J. Liu \\ E-mail: txliujie0523@outlook.com \\ Genet. Mol. Res. 16 (2): gmr16029110 \\ Received September 1, 2016 \\ Accepted February 20, 2017 \\ Published April 20, 2017 \\ DOI http://dx.doi.org/10.4238/gmr16029110 \\ Copyright (C) 2017 The Authors. This is an open-access article distributed under the terms of \\ the Creative Commons Attribution ShareAlike (CC BY-SA) 4.0 License.
}

\begin{abstract}
The aim of the present study is to explore the effect of $I L-6$ gene polymorphisms on the development of keloid scar (KS) in the Chinese Han population. Genotyping of $I L-6$ was performed by the polymerase chain reaction (PCR), followed by restriction fragment length polymorphism assays (PCR-RFLP). Serum level of $I L-6$ was measured using enzyme-linked immunosorbent assay (ELISA). Results indicated that when the $I L-6-572$ CC homozygote genotype was used as the reference group, the GG genotype was found to be associated with a significantly increased risk of KS (GG vs CC: OR $=2.097,95 \% \mathrm{CI}=1.100-3.995, \mathrm{P}=0.025)$. When the $I L-6-572 \mathrm{C}$ allele was used as the reference group, the $\mathrm{G}$ allele was found to be associated with significantly increased risk of $\mathrm{KS}(\mathrm{G} v s \mathrm{C}: \mathrm{OR}=1.317$, $95 \% \mathrm{CI}=1.002-1.730, \mathrm{P}=0.048)$. Furthermore, we observed a marked
\end{abstract}


increase in serum $I L-6$ levels in KS patients with GG genotypes when compared to $\mathrm{KS}$ patients harboring the $\mathrm{CC}$ genotype. In conclusion, our results suggest that $I L-6$ gene polymorphism was associated with keloid scars in the southeastern Chinese Han population.

Key words: Keloid scar, IL-6, Polymorphism

\section{INTRODUCTION}

The formation of keloid scars (KS) after skin trauma remains a challenging clinical problem. KS is a benign, proliferative dermal collagen growth characterized by excessive accumulation of extracellular matrix components, mainly type I collagen, fibronectin, and proteoglycans (Wang et al., 2014). Prevalence of KS varies among different ethnic groups, and its incidence has been estimated to be approximately $4-6 \%$ in the general population (Emami et al., 2012). In the past decades, studies were performed to identify the exact factors responsible for the incidence and development of KS, yet the mechanism of KS formation remains largely unknown (Rossiello et al., 2009). Keloid formation is a complex and multifactorial process that involves both environmental and genetic risk factors. An increasing body of evidence indicated that genetic factors play an important role in the occurrence of KS (Nakashima et al., 2010; Shih and Bayat, 2010; Zhu et al., 2013). Several genetic markers have been identified to be associated with the diagnosis, prognosis, and development of KS (Wu et al., 2012; Yu et al., 2013; Ogawa et al., 2014).

IL-6, a multifunctional cytokine that regulates the immune response, has been intensively studied in the recent years (Fernandes et al., 2015). IL-6 is secreted by T cells and macrophages that are capable of inducing immune responses, including responses to trauma (Singh et al., 2015). The $I L-6$ gene, located on chromosome 7p21-24, has three single nucleotide polymorphisms (SNPs) within its promoter region (Terry et al., 2000). Several studies have demonstrated that SNPs in the -174 promotor region is associated with $I L-6$ gene transcription, which subsequently influences the expression and secretion of IL-6 (Jerrard-Dunne et al., 2004). For example, a $I L-6$ SNP in the -572 promoter region is the substitution of cytosine (C) by guanine $(\mathrm{G})$ (Wang et al., 2016). This substitution may influence $I L-6$ gene transcription and expression level of IL-6, resulting in changes to disease susceptibility (Qi et al., 2012).

Recently, a Japanese study reported keloids are associated with a significant increase in the frequency of $-572 \mathrm{G} / \mathrm{C}$ polymorphisms as compared with that of healthy controls $(0.406$ vs $0.230, \mathrm{OR}=2.34,95 \% \mathrm{CI}=1.337-4.142 ; \mathrm{P}<0.001$ ) (Tosa et al., 2016). However, no studies have examined $I L-6$ gene polymorphism in patients with KS in the Chinese Han population. Therefore, in the present study, we have explored for the first time the effect of $I L-6$ gene polymorphisms on the development of KS in a Chinese Han population.

\section{MATERIAL AND METHODS}

\section{Subjects}

KS patients (224) between the ages of 18-55 years were recruited from outpatients in the Department of Dermatology, at Zhangjiagang First People's Hospital and Taixing People's Hospital. Patients who had KS due to skin disorders, hypertrophic scars, syndrome,

Genetics and Molecular Research 16 (2): gmr16029110 
or genetic or chromosomal disorders were excluded from this case-control study. Clinical diagnoses of KS cases were confirmed by at least two experienced dermatologists. The control subjects were comprised of 246 normal healthy individuals without KS, systemic disorders, autoimmune disorders, and any family history of KS. This study was approved by the ethics committees of our hospital, and written informed consent was obtained from each participant prior to their enrollment in the study.

\section{Sample collection and genotyping}

Venous blood $(5 \mathrm{~mL})$ was collected from each participant into $0.1 \mathrm{mM}$ EDTA tubes, and genomic DNA was isolated with the QIAamp DNA Blood Mini Kit, according to manufacturer's directions. Analysis of $I L-6$ gene polymorphisms at $-174 \mathrm{G} / \mathrm{C}$ and -572 $\mathrm{G} / \mathrm{C}$ were performed via polymerase chain reaction (PCR) followed by restriction fragment length polymorphism assays (PCR-RFLP). The primers and PCR cycling conditions for $I L-6$ gene polymorphisms are listed in Table 1. According to the manufacturer's instructions, PCR products were digested overnight with restriction enzymes, and amplified products were analyzed by electrophoresis on a $2 \%$ agarose gel stained with ethidium bromide.

Table 1. PCR-RFLP primers and conditions for $I L-6$ gene polymorphisms.

\begin{tabular}{l|l|l|c}
\hline SNP & & Sequence & Annealing temperature \\
\hline \multirow{2}{*}{-174} & Forward & $5^{\prime}$-CAG AAG AAC TCA GAT GAC TGG-3' & $60^{\circ} \mathrm{C}$ \\
\cline { 2 - 3 } & Reverse & $5^{\prime}$-GCT GGG CTC CTG GAG GGG-3' & \\
\hline \multirow{2}{*}{-572} & Forward & $5^{\prime}$-GGAGACGCCTTGAAGTAACTGC-3' & $58^{\circ} \mathrm{C}$ \\
\cline { 2 - 3 } & Reverse & $5^{\prime}$-GAGTTTCCTCTGACTCCATCGCAG-3' & \\
\hline
\end{tabular}

\section{Serum IL-6 quantification}

Serum samples were taken from enrolled patients and healthy volunteers, and were stored at $-70^{\circ} \mathrm{C}$ until use. The serum level of IL- 6 was measured using enzyme-linked immunosorbent assay (ELISA). The ELISA kit was purchased from Beijing KeMei Bio-Tech, Ltd. (Beijing, China). In this study, we use IL-1 to induce expression of IL-6.

\section{Luciferase reporter gene assay}

Construction of luciferase reporter gene plasmids was performed as previously described (Chen et al., 2013). A 751-bp sequence of IL-6 gene was amplified from the genomic DNA of healthy volunteers homozygous for the $-572 \mathrm{C}$ allele. The PCR products were digested with Kpn I and Hind III (Takara Biotech., Dalian, China), and were cloned into the pGL3-basic luciferase vector (Promega, Madison, WI, USA). The C allele at nucleotide position -572 was site-specifically mutated to $G$ alleles using a site-directed mutagenesis kit (Stratagene, La Jolla, CA, USA). Luciferase activity was measured using a dual luciferase reporter assay kit (Promega, Madison, WI, USA) $48 \mathrm{~h}$ following transfection, according to manufacturer's specifications.

\section{Statistical analysis}

Statistical analysis was performed using the SPSS version 12.0 software for Windows

Genetics and Molecular Research 16 (2): gmr16029110 
(SPSS Inc., Chicago, IL, USA). Analysis of Hardy-Weinberg was performed using the chisquare test. Difference in genotype and allele frequencies between patients and controls were evaluated using the chi-square test or the Fisher exact test. Logistic regression analysis was performed to determine the association between $I L-6$ gene polymorphisms and KS. All statistical tests were two-sided, and statistical significance was set at a 2 -tailed $\mathrm{P}$ value of $<0.05$.

\section{RESULTS}

\section{Patient characteristics}

The clinical characteristics of the KS cases and control groups are shown in Table 2. There were no significant differences between case and control groups in terms of mean age, gender, tobacco and alcohol use, and BMI $(\mathrm{P}>0.05)$. However, KS patients had significantly higher serum IL-6 levels as compared to those of controls $(\mathrm{P}<0.05)$.

Table 2. Clinical characteristics of all participants.

\begin{tabular}{l|c|c|c}
\hline & KS group $(\mathrm{N}=224)$ & Control group $(\mathrm{N}=246)$ & P value \\
\hline Gender (F:M) & $102: 122$ & $108: 138$ & 0.781 \\
\hline Age (means \pm SD) & $25.3 \pm 8.7$ & $24.8 \pm 9.1$ & 0.543 \\
\hline BMI & $24.3 \pm 2.5$ & $23.9 \pm 2.7$ & 0.095 \\
\hline Tobacco use & 84 & 92 & 0.781 \\
\hline Alcohol use & 62 & 70 & 0.918 \\
\hline Serum IL-6 levels $(\mathrm{pg} / \mathrm{mL})$ & $84.9 \pm 9.3$ & $71.5 \pm 8.8$ & 0.000 \\
\hline
\end{tabular}

\section{Association between $I L-6$ polymorphisms and risk of KS}

The genotype distributions of $I L-6$ polymorphisms in the KS cases and the controls are shown in Table 3. All observed genotype frequencies in both controls and cases conform to Hardy-Weinberg equilibrium ( $\mathrm{P}>0.05$ ). In this study, we found that $I L-6-174$ polymorphism was not associated with risk of KS (Table 3 ). However, when the $I L-6-572 \mathrm{CC}$ homozygote genotype was used as the reference group, the GG genotype was found to be associated with significantly increased risk of $\mathrm{KS}$ ( $\mathrm{GG} v s \mathrm{CC}$ : $\mathrm{OR}=2.097,95 \% \mathrm{CI}=1.100-3.995, \mathrm{P}=0.025$ ). When the $I L-6-572 \mathrm{C}$ allele was used as the reference group, the $\mathrm{G}$ allele was found to be associated with significantly increased risk of $\mathrm{KS}(\mathrm{G} v \mathrm{C}$ : $\mathrm{OR}=1.317,95 \% \mathrm{CI}=1.002-1.730$, $\mathrm{P}=0.048)$.

\section{Table 3. Distribution of $I L-6$ polymorphism in KS and control cases}

\begin{tabular}{|c|c|c|c|c|c|}
\hline Position & Genotypes & $\begin{array}{c}\text { Case }(\%) \\
\mathrm{N}=224 \\
\end{array}$ & $\begin{array}{c}\text { Control (\%) } \\
\mathrm{N}=246\end{array}$ & OR $(95 \% \mathrm{CI})$ & $P$ value \\
\hline \multirow{5}{*}{-174} & GG & $99(44.2)$ & $103(41.9)$ & & \\
\hline & $\mathrm{GC}$ & $101(45.1)$ & $113(45.9)$ & $0.930(0.633-1.366)$ & 0.768 \\
\hline & $\mathrm{CC}$ & $24(10.7)$ & $30(12.2)$ & $0.832(0.455-1.522)$ & 0.646 \\
\hline & G allele & $299(66.7)$ & $319(64.8)$ & & \\
\hline & $\mathrm{C}$ allele & $149(33.3)$ & $173(35.2)$ & $0.919(0.701-1.204)$ & 0.582 \\
\hline \multirow[t]{5}{*}{-572} & $\mathrm{CC}$ & $93(41.5)$ & 117 (47.6) & & \\
\hline & CG & $101(45.1)$ & $111(45.1)$ & $1.133(0.773-1.660)$ & 0.559 \\
\hline & GG & $30(13.4)$ & $18(7.3)$ & $2.097(1.100-3.995)$ & 0.025 \\
\hline & C allele & $287(64.1)$ & $345(70.1)$ & & \\
\hline & G allele & $161(35.9)$ & $147(29.9)$ & $1.317(1.002-1.730)$ & 0.048 \\
\hline
\end{tabular}

Genetics and Molecular Research 16 (2): gmr16029110 


\section{Associations between $I L-6$-572 polymorphism and expression level of IL-6}

Lastly, we explored the association between $I L-6-572$ polymorphism and expression level of IL-6. We observed a marked increase in IL-6 serum levels in KS patients with the GG genotype when compared to KS patients harboring the CC genotype (Figure 1A). As illustrated in Figure 1B, significant luciferase activity was induced in HEK293 cell lines in the presence of IL-1. The reporter gene expression driven by the $-572 \mathrm{G}$ allelic $I L-6$ promoter was approximately 1.55 -fold higher as compared with that driven by its $-572 \mathrm{C}$ allelic counterpart $(1.85 \pm 0.19$ vs $1.20 \pm 0.13, \mathrm{P}<0.05)$.

A

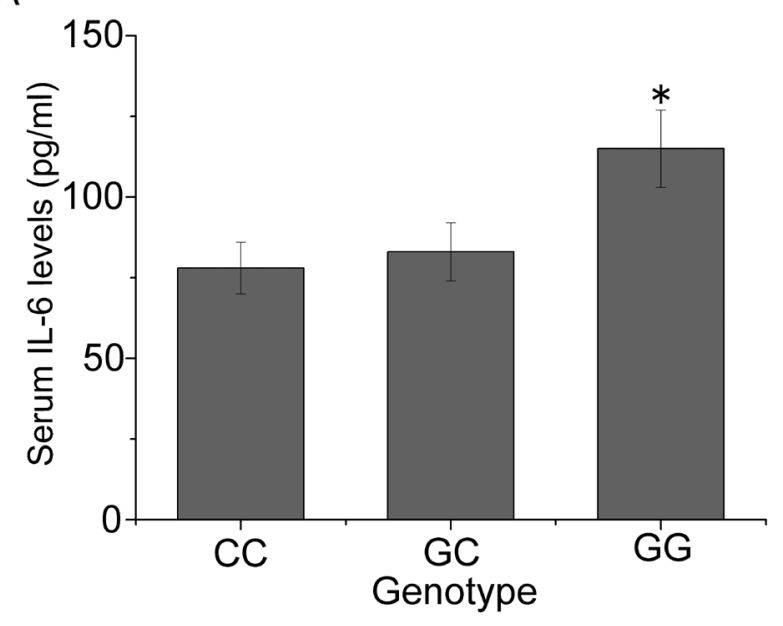

B

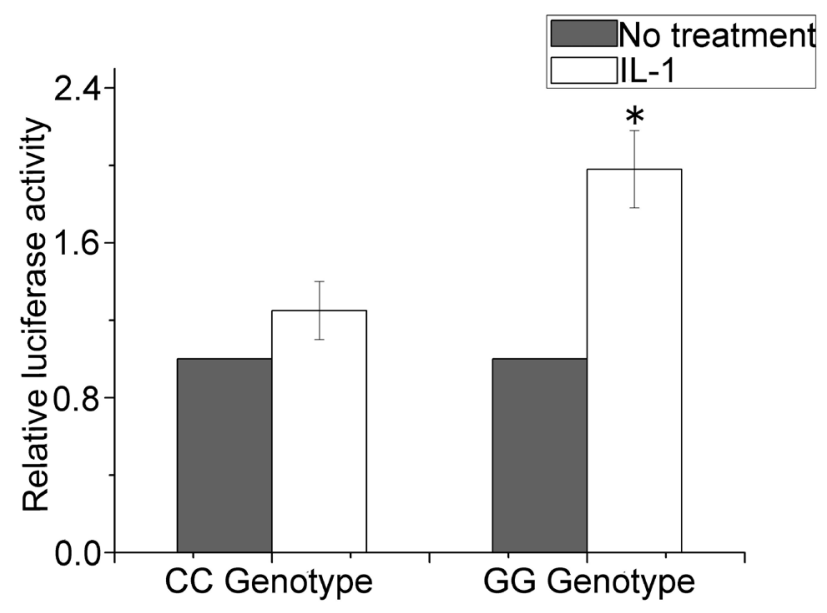

Figure 1. Associations between IL-6 -572 polymorphism and expression of IL-6. A. serum levels of IL-6 were measured by ELISA in KS patients with various genotypes; $* \mathrm{P}<0.05$ as compared to the CC genotype. B. cells were incubated for $48 \mathrm{~h}$ in the absence or presence of IL-1. Firefly luciferase activity was normalized for transfection efficiency by co-transfection with a Renilla $\mathrm{pRL}-\mathrm{TK}$ plasmid; $* \mathrm{P}<0.05$ as compared to control. 


\section{DISCUSSION}

Thepresentstudyis thefirstdemonstrationofanassociation between $I L-6$ polymorphisms and KS in a Chinese Han population. Using a case-control design, we investigated the relationship between two common $I L-6$ polymorphisms and KS in southeastern China. We found that the $I L-6-572 \mathrm{C}>\mathrm{G}$ polymorphism was closely associated with incidence of KS. Carriers with the GG genotype in the $I L-6$ gene were shown to be at higher risk for developing KS. Keloid is defined as an abnormal raised, ill-defined scar that grows beyond the boundary of the original site of a skin injury. It is characterized by a flattened/smooth appearance, and is the size of tumor with varying shapes and sizes (Marneros and Krieg, 2004). Previous studies have demonstrated that KS is familial in nature, and its reported presence in identical twins has long indicated a genetic component to its disease pathology. However, the exact etiopathogenesis of KS remains unclear (Marneros et al., 2001; Yu et al., 2013). Using casecontrol association approaches, studies were performed to attempt to test candidate gene loci that may be involved in formation of keloid scars. Yu et al. (2013) reported that the vitamin D/VDR pathway plays an important role in the development of KS. Han et al. (2014) found that $A D A M 33$ polymorphism may be associated with keloid scars in the northeastern Chinese population. Findings from another studies suggested the common genetic factors can predispose individuals to the development of KS (Zhu et al., 2013). In the present study, we found that $I L-6$ gene polymorphism was associated with keloid scars in the southeastern Chinese Han population.

$I L-6$ is a $27 \mathrm{kDa}$ glycoprotein that is composed of 184 amino acids, and is secreted by activated inflammatory cells such as lymphocyte and macrophage cells (Li et al., 2015). It has been confirmed that IL-6 is involved in many metabolic processes, such as tumor growth, differentiation, and regulation of the immune microenvironment. IL- 6 plays a role in a variety of biological functions by activating multiple signaling pathways. For example, it activates the Ras/Raf/MEK/ERK1/2 pathway to promote tumor cell proliferation (Naka et al., 2002; Ara and Declerck, 2010). The $I L-6$ gene is located on chromosome 7p21, and is composed of 6 exons. There are several polymorphisms in the promoter region of the $I L-6$ gene. Of these polymorphisms, the two most commonly involved and researched are $-174 \mathrm{G}>\mathrm{C}$ and-572 $\mathrm{C}>$ $\mathrm{G}$. Both of these polymorphisms are reported to influence the transcription rate of $I L-6$ (Chérel et al., 2009). In the present study, we found the $I L-6-572$ GG genotype was associated with significantly increased risk of KS. Furthermore, we observed a marked increase in IL-6 serum levels in KS patients with the GG genotypes when compared with KS patients harboring the $\mathrm{CC}$ genotype. Our findings indicated that genetic factors play an important role in the occurrence of KS.

Several limitations in this study need to be addressed. This study was a single-center cohort investigation on a relatively small sample size, and therefore further studies with large independent cohorts are required to confirm the results. Next, we did not detect IL-6 expression in KS tissues. Detection of IL-6 protein in KS tissues will help to clarify the effect of the genetic variants of $I L-6$ gene on KS formation.

\section{CONCLUSION}

In summary, our results suggest that the $I L-6$ gene polymorphism is associated with keloid scars in the southeastern Chinese Han population.

Genetics and Molecular Research 16 (2): gmr16029110 


\title{
Conflicts of interest
}

The authors report no conflict of interest.

\section{ACKNOWLEDGMENTS}

\author{
Research supported by the "Liu Da Gao Feng" Foundation (\#WSN-118).
}

\section{REFERENCES}

Ara T and Declerck YA (2010). Interleukin-6 in bone metastasis and cancer progression. Eur. J. Cancer 46: 1223-1231. http://dx.doi.org/10.1016/j.ejca.2010.02.026

Chen J, Liu RY, Yang L, Zhao J, et al. (2013). A two-SNP IL-6 promoter haplotype is associated with increased lung cancer risk. J. Cancer Res. Clin. Oncol. 139: 231-242. http://dx.doi.org/10.1007/s00432-012-1314-z

Chérel M, Campion L, Bézieau S, Campone M, et al. (2009). Molecular screening of interleukin-6 gene promoter and influence of $-174 \mathrm{G} / \mathrm{C}$ polymorphism on breast cancer. Cytokine 47: 214-223. http://dx.doi.org/10.1016/j. cyto.2009.06.011

Emami A, Halim AS, Salahshourifar I, Yussof SJ, et al. (2012). Association of TGFb1 and SMAD4 variants in the etiology of keloid scar in the Malay population. Arch. Dermatol. Res. 304: 541-547. http://dx.doi.org/10.1007/s00403-012$\underline{1262-0}$

Fernandes MT, Fernandes KB, Marquez AS, Cólus IM, et al. (2015). Association of interleukin-6 gene polymorphism (rs1800796) with severity and functional status of osteoarthritis in elderly individuals. Cytokine 75: 316-320. http:// dx.doi.org/10.1016/j.cyto.2015.07.020

Han J, Xiao J, Wu Q and Hao L (2014). Association of ADAM33 gene polymorphisms with psoriasis in a northeastern Chinese population. Mol. Biol. Rep. 41: 4001-4005. http://dx.doi.org/10.1007/s11033-014-3268-5

Jerrard-Dunne P, Sitzer M, Risley P, Buehler A, et al. (2004). Inflammatory gene load is associated with enhanced inflammation and early carotid atherosclerosis in smokers. Stroke 35: 2438-2443. http://dx.doi.org/10.1161/01. $\underline{\text { STR.0000144681.46696.b3 }}$

Li YY, Zhou CW, Xu J, Qian Y, et al. (2015). Interleukin-6 C-572G gene polymorphism and coronary artery disease in Asian: a meta-analysis of 2511 subjects. Int. J. Clin. Exp. Med. 8: 8995-9003.

Marneros AG and Krieg T (2004). Keloids--clinical diagnosis, pathogenesis, and treatment options. J. Dtsch. Dermatol. Ges. 2: 905-913. http://dx.doi.org/10.1046/j.1439-0353.2004.04077.x

Marneros AG, Norris JE, Olsen BR and Reichenberger E (2001). Clinical genetics of familial keloids. Arch. Dermatol. 137: 1429-1434. http://dx.doi.org/10.1001/archderm.137.11.1429

Naka T, Nishimoto N and Kishimoto T (2002). The paradigm of IL-6: from basic science to medicine. Arthritis Res. 4 (Suppl 3): S233-S242. http://dx.doi.org/10.1186/ar565

Nakashima M, Chung S, Takahashi A, Kamatani N, et al. (2010). A genome-wide association study identifies four susceptibility loci for keloid in the Japanese population. Nat. Genet. 42: 768-771. http://dx.doi.org/10.1038/ng.645

Ogawa R, Watanabe A, Than Naing B, Sasaki M, et al. (2014). Associations between keloid severity and single-nucleotide polymorphisms: importance of rs8032158 as a biomarker of keloid severity. J. Invest. Dermatol. 134: 2041-2043. http://dx.doi.org/10.1038/jid.2014.71

Qi HP, Qu ZY, Duan SR, Wei SQ, et al. (2012). IL-6-174 G/C and -572 C/G polymorphisms and risk of Alzheimer's disease. PLoS One 7: e37858. http://dx.doi.org/10.1371/journal.pone.0037858

Rossiello L, D'Andrea F, Grella R, Signoriello G, et al. (2009). Differential expression of cyclooxygenases in hypertrophic scar and keloid tissues. Wound Repair Regen. 17: 750-757. http://dx.doi.org/10.1111/j.1524-475X.2009.00530.x

Shih B and Bayat A (2010). Genetics of keloid scarring. Arch. Dermatol. Res. 302: 319-339. http://dx.doi.org/10.1007/ s00403-009-1014-y

Singh PK, Chandra G, Bogra J, Gupta R, et al. (2015). Association of interleukin-6 genetic polymorphisms with risk of OSCC in Indian population. Meta Gene 4: 142-151. http://dx.doi.org/10.1016/j.mgene.2015.03.002

Terry CF, Loukaci V and Green FR (2000). Cooperative influence of genetic polymorphisms on interleukin 6 transcriptional regulation. J. Biol. Chem. 275: 18138-18144. http://dx.doi.org/10.1074/jbc.M000379200

Tosa M, Watanabe A and Ghazizadeh M (2016). IL-6 polymorphism and susceptibility to keloid formation in a Japanese population. J. Invest. Dermatol. 136: 1069-1072. http://dx.doi.org/10.1016/j.jid.2016.01.019

Genetics and Molecular Research 16 (2): gmr16029110 
Wang HY, Zhang JJ, Zheng XY, Liu JH, et al. (2016). Association between IL-6 gene (-174 \& -572 G/C) polymorphisms and endometrial adenocarcinoma risk. Pathol. Oncol. Res. 22: 825-829. http://dx.doi.org/10.1007/s12253-016-0073-6

Wang Y, Long J, Wang X and Sun Y (2014). Association of the plasminogen activator inhibitor-1 (PAI-1) Gene -675 4G/5G and -844 A/G promoter polymorphism with risk of keloid in a Chinese Han population. Med. Sci. Monit. 20: 2069-2073. http://dx.doi.org/10.12659/MSM.892397

Wu Y, Wang B, Li YH, Xu XG, et al. (2012). Meta-analysis demonstrates association between Arg72Pro polymorphism in the P53 gene and susceptibility to keloids in the Chinese population. Genet. Mol. Res. 11: 1701-1711. http://dx.doi. org/10.4238/2012.June.29.2

Yu D, Shang Y, Luo S and Hao L (2013). The TaqI gene polymorphisms of VDR and the circulating 1,25-dihydroxyvitamin D levels confer the risk for the keloid scarring in Chinese cohorts. Cell. Physiol. Biochem. 32: 39-45. http://dx.doi. org $/ 10.1159 / 000350121$

Zhu F, Wu B, Li P, Wang J, et al. (2013). Association study confirmed susceptibility loci with keloid in the Chinese Han population. PLoS One 8: e62377. http://dx.doi.org/10.1371/journal.pone.0062377

Genetics and Molecular Research 16 (2): gmr16029110 